\title{
PERAN KELOMPOK TANI DALAM KEGIATAN USAHATANI KAKAO DI DESA KETULUNGAN KECAMATAN SUKAMAJU KABUPATEN LUWU UTARA
}

\author{
Ulfa Lestari ${ }^{1}$, Megawati Idris ${ }^{2}$ \\ 1)Mahasiswa Program Studi Agribisnis, Fakultas Pertanian, Universitas Cokroaminoto Palopo \\ 2) Program Studi Agribisnis, Fakultas Pertanian, Universitas Cokroaminoto Palopo \\ e-mail : 2)megha.idris@gmail.com \\ (Diterima 18 Juli 2019/Disetujui 15 Agustus 2019)
}

\begin{abstract}
The formation of farmer groups will make it easier for farmers to carry out their farming activities. This study aims to examine the role of farmer groups in cocoa farming activities in Ketulungan Village. The approach used in this study is a qualitative descriptive approach. Respondents were cocoa farmer groups selected using a purposive method. Data collection is done by in-depth interviews with respondents and informants. The informants in this study were extension agents both from related institutions and from the private sector. The results of this study indicate that the role of farmer groups in farming activities includes: (1) Farmer groups as a forum for sharing information, namely farmer groups disseminating information obtained from instructors to their members through meetings; (2) Farmer groups as a place of discussion, namely farmer groups as a place to find solutions to problems in cocoa farming activities such as maintenance and handling of pests and diseases; (3) Farmer groups as a forum for learning, namely farmer groups as a place to get knowledge about cocoa cultivation; (4) Farmer groups as production units, namely farmer groups as providers of facilities and infrastructure in farming activities of their members such as providing fertilizer and cocoa seeds; (5) Farmer groups as a place of cooperation, namely farmer groups capable of cooperating with extension agents, PT Mars and its members in carrying out their farming activities. It is expected that farmer groups, more actively collaborate in farming activities and can cooperate with the government and other parties to improve their farming activities.
\end{abstract}

Keywords: role, farmer group, cocoa farming

\begin{abstract}
ABSTRAK
Pembentukan kelompok tani akan lebih mempermudah para petani dalam melakukan kegiatan usahataninya. Penelitian ini bertujuan mengkaji peran kelompok tani dalam kegiatan usahatani kakao di Desa Ketulungan. Pendekatan yang digunakan dalam penelitian ini adalah pendekatan deskriptif kualitatif. Responden adalah kelompok tani kakao yang dipilih menggunakan metode purposive. Pengumpulan data dilakukan dengan wawancara mendalam dengan responden dan informan. Informan dalam penelitian ini yaitu penyuluh baik dari instansi terkait maupun dari pihak swasta. Hasil penelitian ini menunjukkan bahwa peran kelompok tani dalam kegiatan usahatani meliputi: (1) Kelompok tani sebagai wadah berbagi informasi yaitu kelompok tani menyebarkan informasi yang didapat dari penyuluh kepada anggotanya melalui pertemuan; (2) Kelompok tani sebagai tempat diskusi yaitu kelompok tani sebagai tempat mencari solusi dari masalah kegiatan usahatani kakao seperti pemeliharaan dan penanganan hama dan penyakit; (3) Kelompok tani sebagai wadah untuk belajar yaitu kelompok tani sebagai tempat untuk mendapatkan ilmu pengetahuan tentang budidaya kakao; (4) Kelompok tani sebagai unit produksi yaitu kelompok tani sebagai penyedia sarana dan prasarana dalam kegiatan usahatani anggotanya seperti penyediaan pupuk dan bibit kakao; (5) Kelompok tani sebagai wadah kerjasama yaitu kelompok tani mampu bekerjasama dengan penyuluh, PT Mars dan anggotanya dalam melakukan kegiatan usahataninya. Diharapkan para kelompok tani, lebih aktif bekerjasama dalam kegiatan usahatani serta dapat bekerjasama dengan pemerintah maupun pihak-pihak lain untuk meningkatkan kegiatan usahataninya.
\end{abstract}

Kata Kunci: peran, kelompoktani, usahatani kakao 


\section{PENDAHULUAN}

Indonesia dikenal sebagai negara agraris dengan kekayaan alam yang melimpah. Hal tersebut membuat hasil pertanian di Indonesia menjadi maju, bahkan negaranegara Eropa datang ke Indonesia untuk mengimpor bahan pangan atau hasil pertanian Indonesia untuk dijual kembali ke negaranya. Selain hasil pertanian berupa bahan pangan Indonesia juga memiliki produk hasil perkebunan yang diperhitungkan negara-negara lain. Beberapa hasil tanaman perkebunan yang ada di Indonesia yaitu kelapa sawit, tebu, kelapa, kakao dan lain-lain. Tanaman perkebunan kakao Indonesia merupakan tanaman perkebunan terbesar ke dua didunia setelah Pantai Gading dan Gana. Sedangkan di Indonesia sendiri penghasil kakao terbesar berada di Sulawesi Selatan.

Salah satu provinsi di Indonesia yang penghasil kakao cukup besar adalah Sulawesi Selatan. Pada tahun 2016 produksi kakao di Sulawesi Selatan mencapai 145.674 ton dengan luas lahan 239.266 hektar lahan yang tersebar di 22 Kabupaten/Kota (BPS Sulawesi Selatan, 2016). Beberapa daerah Provinsi Sulawesi Selatan yang banyak mengembangkan tanaman kakao yaitu Bulukumba, Soppeng, Sinjai, Bone, Luwu, Bantaeng dan Luwu Utara.

Luwu Utara adalah salah satu daerah penghasil kakao yang besar di Sulawesi Selatan. Pada tahun 2016 Luwu Utara berhasil memproduksi kakao sebesar $26.120,85$ ton dengan luas lahan 38.127,60 hektar kebun kakao yang berada di seluruh wilayah Luwu Utara. Untuk meningkatkan produksi kakao pemerintah membentuk sebuah kelompok sosial di masyarakat khususnya masyarakat yang berprofesi sebagai petani kakao. Peningkatan produksi usahatani secara tidak langsung dipengaruhi oleh keberadaan kelompok tani, para petani secara bersama-sama melakukan pengolahn usahatani. Banyaknya program pemerintah yang sulit menjangkau petani kecil yang jumlahnya cukup banyak menjadi salah satu kendala dalam pelaksanaan program pemerintah, sehingga diharapkan dengan keberasaan kelompok tani akan sangat membantu kegiatan usahatani (Anantanyu, 2011).

Kelompok tani merupakan gabungan beberapa petani yang memiliki persamaan tujuan, persamaan kondisi lingkungan baik social maupun ekonomi. Para petani yang tergabung dalam kelompok tani tersebut terikat secara formal (Dinas Pertanian Ketahanan Pangan, 2002). Berdasarkan pengertian tersebut jumlah kelompok tani di Kabupaten Luwu Utara sebanyak 2500 kelompok tani (BPS Luwu Utara, 2017). Jumlah kelompok tani tersebut sengaja diprogramkan oleh pemerintah untuk melihat peran kelompok tani dalam kegiatan usahatani kakao di Luwu Utara. Selain itu pemerintah juga lebih mudah dalam menyalurkan bantuan kepada petani kakao melalui kelompok tani yang telah terbentuk.

Pembentukan kelompok tani akan lebih mempermudah para petani untuk membantu petani kakao melakukan kegiatan usahataninya. Hal tersebut dikarenakan bekerja berkelompok lebih efisien dibandingkan dengan bekerja secara individu. Tergabungnya para petani dalam kelompok tani dilatarbelakangi oleh persoalan yang sama (Rusdi, 1999). Hal itu dikarenakan adanya kelompok petani dapat saling bertukar pikiran, pengalaman, pengetahuan, dan inovasi-inovasi yang didapatkan dari berbagai sumber untuk meningkatkan kegiatan usahatani kakao. Sehingga mempermudah pemerintah memantau kegiatan-kegiatan yang dilakuakan petani untuk memajukan usahatani kakao dan memberikan solusi yang berkaitan dengan penghambatan dalam melakukan kegiatan usahatani kakao.

Salah satu daerah Luwu Utara yang membentuk kelompok tani yaitu Desa Ketulungan. Desa Ketulungan merupakan desa yang berada di Kecamatan Sukamaju yang umumnya penduduknya berprofesi sebagai petani kakao. Dengan mayoritas penduduk yang berprofesi sebagai petani 
kakao maka masyarakat mulai membentuk kelompok tani. Dengan adanya kelompok tani yang terbentuk dapat membantu petani dalam kegiatan usahatani kakao. Hasil penelitian Triwidarti, dkk (2015) yang menyatakan bahwa, peningkatan pengetahuan petani dapat diperoleh melalui peran-peran yang dilakukan kelompok tani. Mengadakan sekolah lapang sangat membantu para petani dalam menambah ilmu untuk kemudian diaplikasikan pada lahan yang mereka miliki. Peningkatan pengetahuan petani akan berdampak pada peningkatan hasil produksi para petani.

Selain itu menurut hasil penelitian Yani (2010), yang menyatakan bahwa penguasaan teknologi diperoleh oleh petani melalui interaksi anggota kelompok dengan sesama anggota, atau juga anggota kelompok dengan penyuluh melalui kegiatan pelatihan, kunjungan lapang dan magang.

Ada 4 kelompok tani kakao yang terbentuk di Desa Ketulungan. Kelompok tani ini sudah terbentuk cukup lama, namun ada beberapa masalah yang dihadapi antara lain; kurangnya pembinaan terkait kelembagaan kelompok tani sehingga banyak anggota yang tidak aktif dalam kegiatan kelompok, masih minimnya pengetahuan petani yang tergabung dalam kelompok tani terkait budidaya maupun pasca panen dalam usahatani kakao.

Sejalan dengan hasil penelitian Ramdhani, dkk (2013) yang menyatakan bahwa, selama ini efektivitas didalam kelompok tani masih tergolong rendah, ada beberapa faktor penyebabnya antara lain; peran kelompok tani masih terbatas, , struktur organisasi tidak lengkap, produktivitas rendah dan kebanyakan pembentukan kelompok tidak secara partisipatif, bahkan di beberapa daerah ada kelompok tani terbentuk saat tertentu saja seperti pemberian dana dari pemerintah, pemberian bantuan pupuk dan bantuan lainnya.

Sebagian besar penelitian terdahulu meneliti peran kelompok tani dalam peningkatan produksi maupun pendapatan.
Belum ada penelitian yng mengkaji peran kelompok tani dalam kegiatan usahatani kakao. Berdasarkan uraian tersebut, maka penelitian ini bertujuan untuk mengkaji peran kelompok tani dalam kegiatan usahatani kakao di Desa Ketulungan

\section{METODE}

\section{PENGUMPULAN DATA DAN ANALISIS}

Penelitian ini menggunakan pendekatan deskriptif kualitatif, yang menjelaskan, mendeskripsikan apa saja peran kelompok tani dalam kegiatan usahatani kakao. Menurut Punaji (2010), penelitian deskriptif merupakan penelitian yang menjelaskan, memaparkan, mendeskripsikan suatu objek baik berupa angka-angka maupun kata-kata.

Penelitian ini dilakukan di Desa Ketulungan Kecamatan Sukamaju. Daerah penelitian ditentukan secara sengaja (Purposive) dikarenakan Desa ini adalah salah satu Desa penghasil kakao dan memiliki kelompok tani serta anggota yang masih bergabung dan membangun kelompok tani sehingga Desa Ketulungan Kecamatan Sukamaju dipilih sebagai lokasi penelitian. Waktu penelitian dilakukan selama 3 bulan yaitu bulan Maret - Mei 2019.

Adapun yang menjadi responden atau objek penelitian adalah kelompok tani kakao yang ada di Desa Ketulungan yang berjumlah 4 kelompok tani. Penentuan responden dilakukan secara purposive.

Selain petani informasi juga didapatkan dari penyuluh yang ada dilapangan, baik itu penyuluh dari dinas terkait maupun dari pihak swasta dalam hal ini PT. Mars.

Pengumpulan data diawali dengan observasi di lokasi untuk menentukan kelompok tani yang akan menjadi responden serta informan. Selanjutnya pengumpulan data dilakukan dengan wawancara mendalam secara langsung dengan responden dan informan untuk mengkaji peran kelompok tani dalam kegiatan usahatani kakao.

Adapun analisis data yang digunakan dalam penelitian ini adalah analisis 
deskriptif. Menurut Sugiyono (2012), analisis deskriptif bertujuan mengambarkan, menjabarkan serta mendeskripsikan suatu keadaan dari objek atau fenomena yang terjadi dilapangan secara sistematis dan ilmiah untuk menjawab masalah secara aktual. Analisis deskriptif dalam penelitian ini digunakan untuk mengkaji, mengambarkan apa saja peran yang dilakukan oleh kelompok tani dalam kegiatan usahatani kakao.

\section{HASIL DAN PEMBAHASAN}

Kelompok tani dalam penelitian ini merupakan kelompok tani kakao yang terdapat di desa Ketulungan Kecamatan Sukamaju. Ada 4 kelompok tani kakao di Desa Ketulungan.

Kelompok tani yang pertama adalah kelompok tani Mulya Indah yang berdiri sejak tahun 2003 yang diketuai oleh bapak Sutiono. Dengan beraggotakan 25 orang. Kelompok tani ini merupakan kelompok tani terlama yang ada di Desa Ketulungan. Kelompok tani Mulya Tani ini merupakan kelompok tani yang kepengurusannya tidak tetap, dimana kelompok tani ini sudah berganti pengurus sebanyak 5 kali.

Kelompok tani kedua yaitu kelompok tani Sri Abadi yang diketuai oleh bapak Kadar. Kelompok tani ini berdiri sejak 2003 beranggotakan 29 orang yang setiap orang rata-rata memiliki luas lahan 0,5- $1 \mathrm{Ha}$. Anggota kelompok tani Sri Abadi merupakan petani kakao yang baru mulai melakukan penanaman kakao kembali sehingga pengetahuan tentang budidaya kakao masih kurang.

Kelompok tani ketiga yaitu kelompok tani Sinar Tani yang dibentuk pada tahun 2012 yang diketuai oleh bapak Edi Siswanto. Dengan jumlah anggota kelompok sebanyak 25 orang. Sama halnya dengan anggota kelompok tani Sri Abadi anggota kelompok tani Sinar Tani juga baru mulai melakukan penanaman kakao dan masih kurang pengetahuan tentang budidayan kakao.

Kelompok tani keempat yaitu kelompok tani Mekar tani yang terbentuk pada tahun 2008 yang diketuai oleh bapak Heri Irawan. Kelompok tani ini memiliki jumlah anggota 25 orang. Selain bergerak ditanaman perkebunan khususnya coklat kelompok tani ini juga bergerak ditanaman pangan yaitu padi. Kelompok tani yang sudah terbentuk memiliki peran antara lain sebagai wadah berbagi informasi, tempat diskusi, wadah untuk belajar, unit produksi dan wadah kerjasama (pada gambar 1).

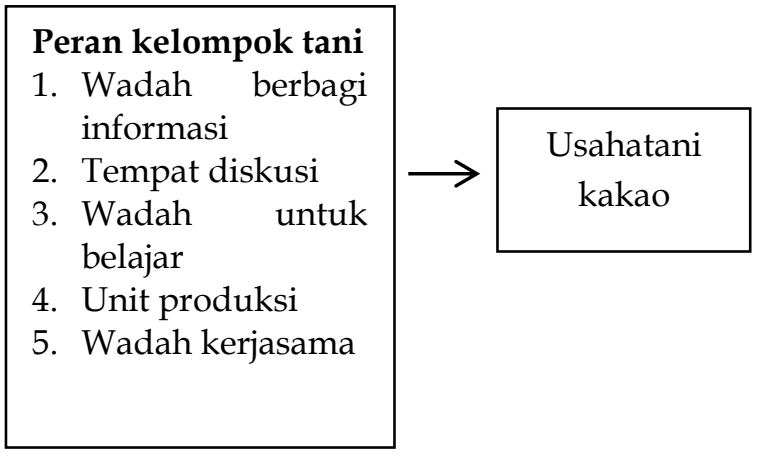

Gambar 1. Peran Kelompok Tani

\section{Peran Kelompok tani dalam Kegiatan Usahatani}

1. Kelompok Tani Sebagai Wadah Berbagi Informasi.

Kelompok tani sebagai wadah berbagi informasi yaitu kelompok tani dapat memberikan informasi yang didapatkan dari penyuluh maupun dari pihak-pihak lain yang paham tentang kakao. Informasi yang didapatkan kelompoktani antara lain yaitu pemilihan bibit kakao yang unggul, pemeliharaan kakao dan penanganan hama dan penyakit pada tanaman kakao. Informasi yang sangat dibutuhkan petani yaitu informasi mengenai penanganan hama dan penyakit serta pengembangan kakao. Dimana pengembangan kakao yang dimaksud yaitu satu pohon kakao terdapat lebih dari 2 jenis kakao.

\section{Kelompok Tani Sebagai Tempat Diskusi}

Kelompok tani sebagai tempat diskusi yaitu kelompok tani menjadi tempat bagi para anggotanya untuk memperoleh solusi 
dari setiap masalah dalam hal budidaya kakao maupun penanganan hama dan penyakit yang menyerang tanaman kakao dan tanaman kakao yang seharusnya sudah mulai berbuah tetapi tidak berbuah. Dalam hal ini kelompok tani bekerjasama dengan penyuluh untuk mengatasi masalah-masalah dalam budidaya kakao melalui forum diskusi yang menghadirkan anggota kelompok dan penyuluh. Selain masalah penanganan hama dan penyakit masalah lain yang dihadapi kelompok tani yaitu kelangkaan pupuk. Biasanya kelompok tani melakukan diskusi 3 bulan satu kali dengan menghadirkan penyuluh, anggota kelompok dan pihak lain seperti pihak PT Mars.

3. Kelompok Tani Sebagai Wadah Untuk Belajar

Kelompok tani sebagai wahana belajar dan berorganisasi merupakan wadah bagi setiap anggota kelompok tani berinteraksi guna peningkatkan pengetahuan, keterampilan, dan sikap dalam berusahatani (Setiadi, 2005). Kelompok tani sebagai wadah untuk belajar yaitu kelompok tani menjadi tempat bagi para anggota untuk mendapatkan ilmu pengetahuan. Salah satu pembelajaran yag didapatkan keompok tani yaitu cara pemeliharaan kakao yang baik. Dimana kelompok tani medapatkan pengetahuan melalui sekolah lapang yang diadakan oleh penyuluh maupun pihak dari PT Mars.

Sekolah lapang diadakan satu bulan 1 kali dan diikuti oleh anggota serta pengurus kelompok tani dan tidak ada paksaan dari pihak penyulu maupun PT Mars untuk ikut sekolah lapang. Dalam kegiatan sekolah lapang para peserta diajarkan materi tentang pemilihan bibit yang unggul, pemeliharaan kakao dan penanganan hama dan penyakit. Dan materi yang didapatkan akan langsung dipraktekkan oleh peserta sehingga peserta akan lebih mudah memahami materi yang diajarkan.

4. Kelompok Tani Sebagai Unit Produksi
Kelompok tani sebagai unit produksi usahatani merupakan suatu kesatuan usaha yang dapat dikembangkan untuk mencapai sekala ekonomis usaha, dengan menjaga kuantitas, kualitas maupun kontinuitas (Permantan, 2013). Kelompok tani sebagai unit produksi yaitu kelompok tani sebagai penyedia sarana dan prasarana produksi, kelompok tani berfungsi untuk mengadakan sarana produksi yang terjangkau dan berkualitas juga memperbaiki prasaranaprasarana yang menunjang sarana produksi. Umumnya kelompok tani membudidayakan kakao jenis BR 45, karena kakao jenis BR 45 buahnya besar serta tahan terhadap hama dan penyakit. Bibit kakao tersebut diperoleh dari kerjasama antara kelompok tani dan PT Mars. Selain itu perawatan kakao yang rutin dilakukan yaitu pemangkasan yang dilakukan satu kali dalam sebulan, pemupukan 2 kali dalam satu tahun yaitu awal musim hujan dan akhir musim hujan pupuk yang digunakan diperoleh kelompok tani dari pemerintah sehingga anggota kelompok tani dapat memperoleh pupuk dengan mudah.

Penanganan hama dan penyakit yang saat ini dilakukan oleh petani yaitu penyemprotan dengan obat kimia akan tetap jika hama dan penyakit masih dapat ditangani dengan bahan alami maka digunakan bahan alami sebagai salah satu cara penanganan hama dan penyakit yang menyerang kakao. Kelompok tani juga mendapatkan penyuluhan yang berasal dari pihak lain seperti PT Mars dalam mengembangkan usahtaninya maupun dalam menangani hama dan penyakit.

5. Kelompok tani Sebagai Wadah Kerjasama

Kelompok tani sebagai wahana kerjasama merupakan suata wadah bagi setiap anggota setiap anggota kelompok untuk mempererat kerjasama antara kelompoktani dengan pihak lain untuk menghadapi ancaman, tantangan, hambatan, serta gangguan dalam berusahatani (Setiadin, 2005). Kelompok tani sebagai 
wadah kerjasama yaitu kelompok tani harus dapat bekerjasama dengan penyuluh maupun pihak-pihak lainnya yang paham mengenai kegiatan usahatani kakaonya serta kerjasama dengan para anggota kelompoknya dalam melakukan kegiatan usahatani kakao.

Pihak-pihak yang bekerjasama dengan kelompok tani antara lain yaitu pemerintah dan PT Mars. Kelompok tani bekerjasama dengan pemerintah dalam hal memperoleh pupuk, sedangkan dengan PT Mars kelompok tani bekerjasa dalam hal penyediaan bibit kakao yang unggul dan cara pemeliharaan kakao serta penanggulangan hama dan penyakit. Selain itu kelompok tani juga bekerjasama dengan anggota kelompoknya yang lain dalam hal menambah wawasan maupun dalam penanaman bibit kakao dan pemeliharaan seperti pemangkasan.

\section{Pembahasan}

1. Kelompok Tani Sebagai Wadah Berbagi Informasi

Berdasarkan hasil penelitian kelompok tani berperan sebagai wadah berbagi informasi yaitu kelompok tani dapat memberikan informasi yang didapatkannya dari penyuluh maupun pihak yang paham mengenai kegiatan usahatani kakao kepada anggotanya. Kelompok tani menyebarkan informasinya melalui pertemuan yang diadakan di rumah ketua kelompok maupun pada saat petani bertemu dikebun. Informasi yang banyak dibagikan kelompok tani saat ini yaitu informasi mengenai pemilihan bibit kakao yang unggul, pemeliharaan kakao dan penanganan hama dan penyakit.

Pemilihan bibit kakao yang unggul yaitu bibit kakao yang memiliki produksi buah tinggi, terbebas dari serangan hama dan penyakit, memiliki perakaran yang kuat dan sudah tersertifikasi oleh lembaga yang berwenang atau lembaga yang berkecimpung di dunia kakao. Pemeliharaan kakao yang baik dan sangat disarankan yaitu GAP (Good Agriculture Practices) dimana GAP terdiri dari pemangkasan, pemupukan, penyemprotan, panen teratur dan sanitasi. Sedangkan dalam penanganan hama dan penyakit petani menggunakan obat kimia maupun alami sesuai dengan hama dan penyakit yang menyerang tanaman kakao petani.

Hasil ini sesuai dengan penelitian Pratama dkk (2016), yang menyatakan bahwa peran kelompok dalam menjalin kerjasama dengan penyuluh sebagai sumber informasi dan untuk membina kelompok agar bisa terus berkembang dan juga membantu petani dalam mencari solusi dari permasalahan yang dihadapi oleh petani. Petani pun bisa mendapatkan informasi melalui kelompok tani lainnya, dengan pertukaran informasi ini diharapakan para petani dapat menambah pengetahuan baik itu dalam teknik budidaya kelapa sawit, penggunaan pupuk yang benar pemasaran hasil panen, serta teknologi dan inovasi yang lebih canggih dimasa kini.

\section{Kelompok Tani Sebagai Tempat Diskusi}

Kelompok tani sebagai tempat diskusi yaitu kelompok tani menjadi tempat bagi para anggotanya untuk memperoleh solusi dari setiap masalah dalam hal budidaya kakao maupun penanganan hama dan penyakit yang menyerang tanaman kakao dan tanaman kakao yang seharusnya sudah mulai berbuah tetapi tidak berbuah. Dalam hal ini kelompok tani bekerjasama dengan penyuluh untuk mengatasi masalah-masalah dalam budidaya kakao, melalui forum diskusi yang menghadirkan anggota kelompok dan penyuluh serta pihak PT Mars dan diadakan di rumah ketua kelompok tani.

Penyakit yang menyerang tanaman kakao responden yaitu jamur akar, cara penanganan penyakit jamur akar yaitu dengan cara membuat lubang isolasi yang sedalam satu meter dan diberi dolomit dan pupuk urea setelah itu didiamkan selama beberapa bulan hingga penyakit jamur akarnya menghilang dan setelah itu lokasi yang terkenak jamur akar siap untuk ditanami kakao kembali. Sedangkan hama yang menyerang tanaman kakao petani yaitu 
pengerek buah kakao dimana penanganan yang disarankan menggunakan sarungisasi. Masalah selanjutnya yang dihadapi petani kakao yaitu tidak berbuahnya kakao yang seharusnya pada usia 9 bulan kakao sudah dapat menghasilkan buah tetapi kakao petani tidak berbuah walaupun sudah menggunakan bibit unggul dan tersertifikasi. Masalah tersebut dikarenakan iklim di Desa Ketulungan tidak cocok dengan tanaman kakao yang ditanam petani. Menghadapi masalah-masalah tersebut kelompok tani membentuk sebuah forum diskusi yang dihadiri oleh para anggota kelompok dan penyuluh. Kegiatan diskusi tersebut dilakukan di rumah ketua kelompok dan diadakan 3 bulan sekali oleh kelompok tani.

Hasil ini sesuai dengan penelitian Pratama dkk (2016), yang menyatakan bahwa Kelompok tani berperan dengan baik dalam hal merumuskan kesepakatan untuk memecahkan masalah dan melakukan kegiatan bersama seperti selalu berdiskusi apabila kelompok maupun anggota memiliki masalah, membuat daftar kegiatan yang akan dilakukan bersama dan kemudian didiskusikan bersama dengan anggota.

\section{Kelompok Tani Sebagai Wadah Untuk Belajar}

Kelompok tani sebagai wadah untuk belajar yaitu kelompok tani menjadi tempat bagi para anggota untuk mendapatkan ilmu pengetahuan. Salah satu pembelajaran yang didapatkan keompok tani yaitu cara pemeliharaan kakao yang baik. Dimana kelompok tani mendapatkan pengetahuan melalui sekolah lapang yang diadakan oleh penyuluh maupun pihak dari PT Mars. Halhal yang diajarkan penyuluh pada saat melakukan sekolah lapang yaitu pemilihan bibit unggul, pemangkasan, pemupukan, dan hama dan penyakit yang menyerang kakao. Sedangkan sekolah lapang yang diadakan oleh PT Mars diajarakan tentang perkawinan bunga kakao, fertigasi, pemangkasan, pemupukan, sanitasi dan hama dan penyakit yang menyerang kakao.

Pemangkasan yaitu menghilangkan cabang-cabang kakao yang sudah tidak produktif lagi. Pemangkasan ada tiga yaitu pemangkasan pemeliharaan, pemangkasan produksi atau pemangkasan berat dan pemangkasan bentuk. Diantara tiga macam pemangkasan, responden lebih rutin melakukan pemangkasan pemeliharaan. Pemangkasan pemeliharaan dilakukan satu bulan satu kali dengan cara memangkas cabang cupon yang tumbuh pada batang utama kakao dan cabang yang terkenak penyakit VSD. Sedangkan pemangkasan berat atau pemangkasan produksi dilakukan satu tahun satu kali. Pemupukan dilakukan 2kali dalam satu tahun dengan menggunakan pupuk NPK poska, SP36, dan urea dan dilakukan pada awal musim hujan dan akhir musim hujan.

Berdasarkan uraian diatas dapat disimpulkan bahwa kelompok tani di Desa Ketulungan berperan sebagai wadah untuk belajar bagi para anggotanya dalam melakukan kegiatan usahatani kakao. Hal ini sesuai dengan penelitian Palar dkk (2019), yang menyatakan bahwa peran kelompok tani sebagai kelas belajar bertujuan untuk meningkatkan pengetahuan, sikap, dan keterampilan tergolong cukup baik karena dari usaha pertanian yang dilakukan dalam kelompok membuat para anggotanya untuk menambah pengetahuan sikap dan keterampilan dalam bertani.

\section{Kelompok Tani Sebagai Unit Produksi}

Kelompok tani sebagai unit produksi yaitu kelompok tani sebagai penyedia sarana dan prasarana produksi, kelompok tani berfungsi untuk mengadakan sarana produksi yang terjangkau dan berkualitas juga memperbaiki prasarana-prasarana yang menunjang sarana produksi. Umumnya kelompok tani membudidayakan kakao jenis BR 45 karena kakao jenis BR 45 buahnya banyak dan besar serta tahan terhadap hama dan penyakit. Bibit kakao tersebut diperoleh dari kerjasama antara kelompok tani dan PT Mars. Selain itu perawatan kakao yang rutin dilakukan yaitu pemangkasan yang dilakukan satu kali dalam sebulan, 
pemangkasan yang dilakukan tersebut merupakan pemangkasan pemeliharaan. Pemupukan dilakukan diawal musim hujan serta diakhir musim hujan. Pupuk yang digunakan diperoleh kelompok tani dari pemerintah sehingga anggota kelompok tani dapat memperoleh pupuk dengan harga terjangkau. Pemilihan bibit kakao yang ditanam oleh petani berdasarkan hasil rekomendasi dari penyuluh dan pihak PT Mars. Bibit BR 45 dipilih oleh pertani responden karena clon BR 45 memiliki buah besar, biji yang besar dan bobot yang berat dan jangka waktunya sedikit lebih lama. Walaupun demikian petani tetap menanam clon jenis ini dikarenakan harga bibit yang ditawarkan terbilang murah untuk kelompok tani sekitar 3500 per polybag. Harga tersebut lebih murah dibandingkan harga yang diberikan untuk petani yang tidak gabung dalam kelompok tani. Harga bibit kakao untuk petani biasa yaitu 5000 per polybag.

Pupuk didapatkan kelompok tani melalui pengajuan proposal yang dibuat oleh pengurus kelompok dan dibantu oleh penyuluh. Proposal yang sudah dibuat akan dimasukan kedinas pemerintahan terkait. Apabila proposal disetujui maka kelompok tani akan mendapat bantuan pupuk dengan harga yang relatif murah. Setelah pupuk sampai ke kelompok tani maka akan dibagikan ke anggota kelompok dengan jumlah satu orang maksimal mendapatkan 2 pupuk. Hal itu dilakukan untuk mengantisipasi agar semua anggota kelompok mendapatkan pupuk sama rata. Akan tetapi tidak semua kelompok mendapatkan pupuk, hal tersebut dikarenakan tidak semua pengurus mau membuat proposal.

Sesuai dengan penelitian Palar dkk (2019), yang menyatakan bahwa peran kelompok tani dalam memfasilitasi petani dalam penerapan bahan, alat dan cara cukup berperan tinggi, petani merasa terbantu dalam kegiatan usahataninya dengan adanya kerjasama yang baik antar kelompok tani dengan penyedia sarana produksi.
5. Kelompok tani sebagai wadah kerjasama

Kelompok tani sebagai wadah kerjasama yaitu kelompok tani menjadi salah satu tempat untuk bekerjasama dengan pihakpihak yang paham mengenai kegiatan usahatani kakaonya dan kerjasama antara kelompok tani dengan anggotannya. Pihakpihak yang bekerjasama dengan kelompok tani antara lain yaitu pemerintah dan PT Mars. Kelompok tani bekerjasama dengan pemerintah dalam hal memperoleh pupuk, sedangkan dengan PT Mars kelompok tani bekerjasa dalam hal penyediaan bibit kakao yang unggul dan cara pemeliharaan kakao serta penanggulangan hama dan penyakit. Selain itu kelompok tani juga bekerjasama dengan kelompok tani yang lain dalam hal menambah wawasan maupun dalam penanaman bibit kakao dan pemeliharaan seperti pemangkasan.

Kerjasama yang dilakukan kelompok tani dengan anggotannya menyangkut tentang pemeliharaan kakao yang berupa pemangkasan. Kerjasama yang dilakukan berupa pemangkasan karena pemangkasan merupakan kegiatan pemeliharaan kakao yang rumit dan memerlukan teknik yang tepat sehingga tidak semua anggota kelompok tani paham dengan baik. Selain pemangkasan penanaman kakao juga dilakukan kelompok tani bersama para anggota karena penanaman kakao memerlukan pengajiran dan jarak tanam yang tepat sehingga petani tidak sembarangan menanam kakao.

Kerjasama lain yang dilakukan kelompok tani yaitu kerjasama antara kelompok tani dengan pihak pemerintah. Kerjasama kelompok tani dengan pihak pemerintah berupa penyaluran pupuk yang bersubsidi dari pemerintah kepada kelompok tani. Sehingga kelompok tani tidak mengalami kesulitan untuk mendapatkan pupuk dan dengan harga yang relatif terjangkau. Selain dengan pemerintah kelompok tani bekerjasama dengan pihak PT Mars dalam mendapatkan bibit unggul yang tersertifikasi dan pihak PT Mars 
menawarkan kerjasama dalam pemeliharaan kakao berupa pemangkasan dan penanaman.

Hal ini sesuai dengan penelitian Istiyani (2016), yang menyatakan bahwa bentuk kerjasama yang paling dirasakan responden saat bergabung dengan kelompok tani adalah kerjasama dalam hal menyediakan saprotan serta menyediakan informasi dan teknologi. Dalam hal ini, kelompok tani memberikan bantuan berupa Handtracktor sehingga membantu mengurangi biaya dan tenaga untuk melakukan pengolahan lahan sawah. Selain itu, kelompok tani juga membantu menyediakan benih yang dapat dibeli oleh anggota kelompok. Dari segi penyedia informasi dan teknologi, kelompok tani bekerjasama dengan penyuluh lapang serta dinas-dinas terkait lainnya.

\section{KESIMPULAN DAN SARAN}

\section{KESIMPULAN}

Hasil penelitian menunjukkan bahwa peran kelompok tani dalam usahatani kakao di Desa ketulungan antara lain; Kelompok tani sebagai wadah berbagi informasi, kelompok tani sebagai wadah diskusi, kelompok tani sebagai wadah belajar, kelompok tani sebagai unit produksi, dan kelompok tani sebagai wadah kerjasama.

\section{SARAN}

1. Saran bagi petani untuk lebih memanfaatkan kelompok tani yang sudah terbentuk serta lebih aktif bekerjasama dengan anggota kelompok tani dalam kegiatan usahatani kakao.

2. Diharapkan kelompok tani bekerjasama dengan pemerintah maupun pihak swasta dalam hal pembinaan kelompok tani baik secara kelembagaan maupun dalam hal usahatani.

\section{DAFTAR PUSTAKA}

Anantayu, S. 2011. Kelembagaan Petani, Peran Dan Strategi Pengembangan
Kapasitasnya. Jurnal SEPA 7(2): 102 109.

Badan Pusat Stastiktik. 2016. Kabupaten Luwu Utara.

Dinas Pertanian Tanaman Pangan Provinsi Kalimantan Timur. 2002. Petunjuk Pengembangan, Bimbingan Penyuluhan dan Pengembangan Kelompok Tani .Samarinda.

Istiyani, A. 2016. Peranan Kelompok Tani Meningkatkan Produktivitas Usaha Tani Anggota. Skripsi. Bogor. Fakultas Ekologi Manusia. Institut Pertanian Bogor.

Pratama, B.P., Sayamar, E dan Tety, E 2016.

Peran Kelompok Tani Dalam Meningkatkan Pendapatan Petani Swadaya Kelapa Sawit Di Desa Bukit Lingkar Kecamatan Batang Cenaka Kabupaten Indragiri Hulu. Jurnal Jom Faperta 3(2).

Palar, Romario Hevrain dkk, 2019. Peran Kelompok Tani Terhadap Anggota Kelompok Tani Kelelondei Indah Di Desa Ampreng Kecamatan Langawan Barat. Jurnal. Agri Sosial Ekonomi 15 (1).

Ramdhani, H., Nulhaqim, S.A., dan Fdyansah, M. 2013. Peningkatan Kesejahteraan Petani dengan Penguatan Kelompok Tani. Prosiding KS:Riset \& PKM 2 (3) : 301-444

Rusdi, R. 1999. Sosiologi Teks Dan Terapan. Kencana Prenata Media Grup : Jakarta.

Sugiyono. 2012. Metodologi Penelitian. Alfabet : Bandung.

Sugiyono. 2013. Metode Penelitian Pendidikan. CV Alfabeta : Bandung.

Triwidarti,T., Suryadi, B., dan Sukidin. 2015. Peran Kelompok Tani Sampurna dalam Meningkatkan Pengetahuan Petani dan Hasil Produksi Padi di Desa Jenggawah Kecamatan 
Jnggawah Kabupaten Jember. Artikel Ilmiah Mahasiswa 1(1):1-6.

Yani, D.E. 2010. Persepsi Anggota terhadap Peran Kelompok Tani dalam Meningkatkan Kemampuan

Penguasaan Teknologi Budidaya. Jurnal Matematika, Sains dan Teknologi 11(2) : 133-145. 